\title{
Knowledge and Attitude of Adolescent students' Toward Premarital Examination in Secondary Schools at Assiut City
}

\author{
Marwa M. Kamel ${ }^{1}$, Hoda Ibrahim Fahmy ${ }^{2} \&$ Shimaa E. Aly ${ }^{3}$. \\ 1. Clinical Demonstrator in Community Health Nursing, Faculty of Nursing, Assuit University, Egypt. \\ 2. Professor of Community Health Nursing- Faculty of Nursing, Assuit University, Egypt. \\ 3. Lecturer of Community Health Nursing-Faculty of Nursing, Assuit University, Egypt.
}

\begin{abstract}
Background: Premarital examination is one of the health promotion activities that provided in the maternal and child health service programs. This aimed to early detection of any health problem and treatment, Preparation for marriage; providing family life education. The community health nurses play an fundamental role in providing pre marital care services that include assess hereditary risk, provide information, and appropriate helpful counseling.The study aimed to: To assess students' knowledge and attitude toward premarital examination. Subjects and Methods: Descriptive cross sectional research design was used in this study. Multistage random sample was used in this study. The study was conducted in 4 randomly selected secondary schools. The total number of sample was 879 students. Two tools were used in this study the first tool included personal characteristics and student's knowledge, while the second tool lickert scale toward premarital examination. Results: regarding knowledge $66.0 \%$ of studied students had poor score of knowledge while $50.4 \%$ of them had negative attitude toward premarital examination. Conclusion: A significant gap in student's knowledge regarding premarital examination, while about half of them had positive attitude, also there is positive Correlation between total score of students knowledge and attitude about premarital examination. Recommendation: Conducting counseling sessions with social workers in schools to convey information to students about premarital examination
\end{abstract}

\section{Key words: Knowledge, Attitude, Adolescent Student,Premarital Examination \& Secondary School.}

\section{Introduction}

Premarital examination(PME) :is a group of tests in which couples that are going to get married are tested for genetic, infectious and blood transmitted diseases to prevent any risk of transmitting any disease to their children (Rhman et al., 2014) The premarital investigation consists of three packages; it includes Basic package which include; Complete blood count (CBC), Abnormal Hemoglobin studies, Sexually transmitted diseases investigation(Human immune deficiency virus (HIV) antibody screening (3rd Generation), surface antigen of the hepatitis B virus( BsAG ) screening and Advanced Package which contain; Male infertility test, Female infertility test and Advanced Genetic Package that consists of basic tests, fertility tests and blood karyotyping (Hemamalini, 2017)

Healthy marriage program is considered a national, communal responsibility. Thus awareness and preventive program aims to Limit the spread of some genetic blood diseases as sickle-cell anemia (SCA) and thalassemia, and some infectious diseases as hepatitis B, C and AIDS/HIV, Diminish the economic burden of the family and community, lessen pressure over health institutions and blood banks ,Stay away from the social and psychological problems for families whose children affected and Disseminate awareness with consider to the concept of the comprehensive, healthy marriage (Hemamalini, 2017)

A number of countries in the Mediterranean and Middle Eastern regions have implemented mandatory Premarital Marital Screening and Genetic Counseling program to reduce the prevalence of genetic disorders. Mandatory PME refers to policies that make certain medical examinations a necessary condition for marriage, especially in which diseases are endemic for various legal and cultural reasons, and other educational and cost-effectiveness factors (Howard, 2015).

In the United Arab Emirates, screening for syphilis, hepatitis B, and HIV in new marriages is required by law, while in Nigeria, religious factors drive HIV screening. However, voluntary PME is more dominant form than the mandatory form worldwide probably due to ethical considerations. (Gu et al., 2014) In Kuwait Mandatory premarital screening program have been implemented into high-risk populations worldwide since the 1970 with a remarkable success In order to avoid the financial, psychological and social burdens that are usually present among families with children affected by genetic and chronic infectious diseases (Al-Enezi \& Mitra ,2017)

In Saudi Arabia; Premarital Screening and Genetic Counseling (PMSGC) program was recognized by law in December 2003 and implemented in February 
2004. The program, named the "Healthy Marriage Program," is part of a national project spearheaded by the Saudi Ministry of Health (Ibrahim et al., 2013).

In Egypt, the first medical center has been working since mid-2001. Despite the success of this center in control of many health problems, attendants' number is still few. It seems that many young couples remain skeptical about the efficacy of PMC and less likely to convince (Ahmed et al., 2015).

The new article that has been added in accordance with Law no. 126 of 2008 to Law no. 143 of 1994 on Civil Status "The State ensures carrying out a medical examination for those wishing to get married to ensure that they are free from diseases that may affect their lives or the health of either one of them, or the health of their offspring; and informs them of the results of the examination. A decree from the Minister of Health in agreement with the Minister of Justice shall determine those diseases, the types of examination and procedures, and the parties licensed to conduct the examination"(The national counsil for childhood \& motherhood in Egypt, 2008).

The community health nurses play an fundamental role in providing pre marital care services that include assess hereditary risk, provide information, discuss available testing options and provide appropriate helpful counseling(Amin, 2015) Nursing is an integral part of the health care system and nurse's direct energies towards the promotion, maintenance \& restoration of health and play a valuable role in changing females believes, behaviors which the providing health education about premarital counseling, discussing the benefits of premarital counseling (Said, 2017) Nurses can facilitate the process and offer individuals the option of support groups for families, health education and the media can work together to increase awareness in the premarital adolescent students(Gabriel \& Matthew,2013).

\section{Significance of the study}

Premarital examinations is one of the significant strategies for prevention of inherited diseases and congenital anomalies and decrease the economic burden of the family whose children affected with inherited,congenital anomalies.So the researchers conduct this study to assess adolescent students' knowledge and attitude regarding premarital examination.

\section{Aim of the study}

1. To assess students' knowledge toward premarital examination.

2. To identify students' attitude toward premarital examination.

\section{Reseach question}

1-Are the students have good knowledge regarding premarital examination?

2-What are the student's attitude toward premarital examination?

3- Are there relation between students' knowledge and their attitude toward premarital examination?

\section{Subjects \& Methods \\ Research design}

Descriptive cross sectional research design was used in this study.

Setting

The study was conducted in 4 randomly selected schools which include (secondary Commercial for Boys, Jamal Farghali Sultan Secondary school for Boys in East city, Alwaleedeya Secondary school for girls and Secondary Industrial for Girls in West the city).In this study was conducted in boys and girls schools due to premarital examination done with partner so that sample included boys and girls schools.

\section{Sampling}

Multistage random sample was used in this study. Assiut city include 43 public secondary schools which divided into 26 East and 17 West Assiut city. The study was conducted in 4 randomly selected schools.All grades (first, second and third grade)were included in this study, the researchers enters the available lessons and only students who available and accept to participate in the study included.

\section{Sample and sampling}

The total number of students in selected randomly schools are 2938 students With the software EPI /Info, version 3,3 with $99 \%$ confidence interval (CI), the estimated sample size found to be 664 students and increased about $7 \%$ from the total number of students in all selected schools to be 879 students to avoid drop out and refuse from some of them; it included about $30 \%$ from each selected schools. The number of students were selected randomly in every school. The following table cleared the number of students in each school

\begin{tabular}{|l|c|c|}
\hline \multicolumn{1}{|c|}{ Schools } & $\begin{array}{c}\text { Actual } \\
\text { Number of } \\
\text { students }\end{array}$ & $\begin{array}{c}\text { Sample size } \\
\text { (30\% from total } \\
\text { sample size of each } \\
\text { school) }\end{array}$ \\
\hline $\begin{array}{l}\text { Secondary Commercial } \\
\text { Boys } \\
\text { (East) }\end{array}$ & 247 & 74 \\
\hline $\begin{array}{l}\text { Alwaleedeya Secondary } \\
\text { Girls(West) }\end{array}$ & 545 & 163 \\
\hline $\begin{array}{l}\text { Jamal Farghali Sultan } \\
\text { Secondary Boys(East) }\end{array}$ & 646 & 193 \\
\hline $\begin{array}{l}\text { Secondary Industrial } \\
\text { Girls(West) }\end{array}$ & 1500 & 449 \\
\hline Total & 2938 & 879 \\
\hline
\end{tabular}




\section{Tools of study}

After reviewing related literature; two proper tools was used for data collection ;it included:

Tool (1): Self, administered questionnaire was developed by researcher to collect information from the students, it included two parts:

Part 1: personal characteristics of the students; it included: name of school ,age, sex, grade, residence, marital status, parents' education and occupation.

Part 2: It consisted of questions to assess students' knowledge regarding premarital examination which included definition, Beneficiary category(who will benefit from premarital examination), ,Importance ,diseases that can be detected by it, Types of pre marital investigation, Suitable time for examination, source of information, Service providers, Place of premarital examination.(Mohamed, 2015 \& Jamiu, 2016).

The scoring system for knowledge

The total grades of knowledge were (32)grades; one grade for each correct answer and zero for incorrect answer and doesn't know. Total score was calculated by summing up and convert into a percent score as following:- Poor < 50\% Satisfactory 50- 70\% Good > 70\% (Abd- El Rahman,2014).

\section{Tool (II)}

Lickert scale toward premarital examination developed by (Ibrahim 2013) This scale assess the attitude of students' regarding Pre-marital examination . It consisted of 14 statements five likertscale . Each positive statement have response as Strongly Disagree(1), Disagree(2), No opinion (3), Agree(4) and Strongly Agree(5) and reversed for positive statement .

\section{Scoring system for attitude}

The total score was calculated by summing -up and then converting into a percentage score. Students' attitude was considered positive if the score was $\geq 70 \%$ and negative attitude if the score was $<70 \%$ ).(Ibrahim et al., 2009).

\section{Validity of tools}

The tools were transferred to Arabic language and reviewed to ascertain their content validity by five experts in nursing sciences as: Gynecological and obstetrics nursing, family and community health nursing, who reviewed the tools for clarity, relevance, comprehensiveness, understanding and applicability. According to the opinions of experts the modification were done .

Reliability: Reliability of tool II, was assessed by using alpha-cron-bach test to test the internal consistency were ( $\mathrm{r} 2=0.877)$.

Methodology.

\section{A-Administrative phase}

An official letter approval was obtained from the Dean of the Faculty of Nursing, Assiut University to
Assiut Directorate of Education and then send to central agency for public mobilization and statistics after that to centralized management of security ;finally to directors of the schools. The letter included a permission to carry out the study and purpose of it.

Pilot study

It aimed to test the clarity of the tools and estimate the required time to fill the questionnaires. It was carried out before starting of data collection on $10 \%$ (80) of adolescent students; who included in the sample.

\section{B-Data collection phase Ethical consideration}

The researcher followed all ethical issues in conducting the research .Consent was secured orally from the participants who are willing to participate in the study. The participants were informed that participation in this study is voluntary ; they can withdraw at any time during the study without giving reasons.The researcher have explained the aim of the study to all schools students in the study sample. They assured that any obtained information would be strictly confidential.

\section{Field work}

Data was collected in the period from the mid of February to the end of April, 2018. The researcher took two days each week, 35-45 students student who agree to participate in the study per day and filling of questionnaire took from15-20 minutes by students .

\section{Statistical analysis}

The obtained data was reviewed, prepared for complete entry coded, analyzed and tabulated by using SPSS version 19 (Statistical Package for Social Science). Data were presented as number, percentage, mean \pm , standard deviation. Chi-square test was used to compare between qualitative variables. Pearson correlation was done to measure correlation between quantitative variables. Statistical significance was considered at $\mathrm{p}$-value were less than $\mathrm{P}<0.05$. 


\section{Results}

Table (1): Distribution of studied students regarding to their personal characteristics, $(n=879)$.

\begin{tabular}{|c|c|c|}
\hline Personal characteristics: & No. (879) & $\%$ \\
\hline \multicolumn{3}{|l|}{ Age:(years) } \\
\hline$<16$ & 255 & 29.0 \\
\hline $16-<18$ & 467 & $\mathbf{5 3 . 1}$ \\
\hline$\geq 18$ & 157 & 17.9 \\
\hline Mean \pm SD (Range) & \multicolumn{2}{|c|}{$16.26 \pm 1.14(14.0-19.0)$} \\
\hline \multicolumn{3}{|l|}{ Sex: } \\
\hline Male & 285 & 32.4 \\
\hline Female & 594 & 67.6 \\
\hline \multicolumn{3}{|l|}{ Residence: } \\
\hline Rural & 318 & 36.2 \\
\hline Urban & 561 & 63.8 \\
\hline \multicolumn{3}{|l|}{ Father education: } \\
\hline Illiterate & 53 & 6.0 \\
\hline Read \& write & 103 & 11.7 \\
\hline Basic education & 132 & 15.0 \\
\hline Secondary & 345 & 39.2 \\
\hline University & 246 & 28.0 \\
\hline \multicolumn{3}{|l|}{ Mother education: } \\
\hline Illiterate & 143 & 16.3 \\
\hline Read \& write & 97 & 11.0 \\
\hline Basic education & 108 & 12.3 \\
\hline Secondary & 344 & 39.1 \\
\hline University & 187 & 21.3 \\
\hline \multicolumn{3}{|l|}{ Father occupation: } \\
\hline Employee & 574 & 65.3 \\
\hline Skilled worker & 58 & 6.6 \\
\hline Free business & 194 & 22.1 \\
\hline Farmer & 29 & 3.3 \\
\hline Does not work & 21 & 2.4 \\
\hline Died & 3 & 0.3 \\
\hline \multicolumn{3}{|l|}{ Mother occupation: } \\
\hline Housewife & 627 & 71.3 \\
\hline Working & 252 & 28.7 \\
\hline
\end{tabular}

Table (2): Distribution of studied student's knowledge about premarital examination, $(n=879)$.

\begin{tabular}{|l|c|c|}
\hline \multicolumn{1}{|c|}{ Knowledge } & No. (879) & \% \\
\hline Importance of premarital examination:\# & & 34.4 \\
\hline Early detection of diseases & 302 & $\mathbf{5 0 . 9}$ \\
\hline Gain information about reproductive health & 447 & 25.5 \\
\hline Ensure that couple are free from genetic diseases & 224 & 43.5 \\
\hline Ensure that couple are free from infectious diseases & 382 & $\mathbf{3 7 . 4}$ \\
\hline Don't know & 329 & 32.1 \\
\hline Diseases can be detected by premarital examination:\# & & 12.3 \\
\hline Sexual transmitted diseases & 282 & 4.3 \\
\hline Viral hepatitis B & 108 & 24.6 \\
\hline Infertility & 38 & 4.8 \\
\hline AIDS & 216 & 42 \\
\hline Genetic hereditary diseases & 42 & \\
\hline
\end{tabular}




\begin{tabular}{|l|c|c|}
\hline \multicolumn{1}{|c|}{ Knowledge } & No. (879) & \% \\
\hline Don't know & 588 & $\mathbf{6 6 . 9}$ \\
\hline \hline Premarital investigation :\# & & 33.0 \\
\hline Viral hepatitis C & 290 & 29.2 \\
\hline Viral hepatitis B & 257 & 33.7 \\
\hline Diabetes analysis & 296 & 33.8 \\
\hline Complete blood count & 297 & 35.2 \\
\hline Blood group analysis & 309 & 34.8 \\
\hline Rises factor analysis (RH) & 306 & 28.6 \\
\hline HIV testing & 251 & 35.7 \\
\hline Examination of seminal fluid & 314 & 31.5 \\
\hline Urine Analysis & 277 & \\
\hline
\end{tabular}

(\#) More than one answer was allowed

Table (3): Relation between studied student's knowledge about premarital examination and their parent's education \&occupation in secondary school at Assiut city.

\begin{tabular}{|c|c|c|c|c|c|c|c|}
\hline \multirow{3}{*}{ Items } & \multicolumn{6}{|c|}{ Knowledge level } & \multirow{3}{*}{ P-value } \\
\hline & \multicolumn{2}{|c|}{ Poor } & \multicolumn{2}{|c|}{ Fair } & \multicolumn{2}{|c|}{ Good } & \\
\hline & No. & $\%$ & No. & $\%$ & No. & $\%$ & \\
\hline Father education: & & & & & & & \multirow{6}{*}{0.151} \\
\hline Illiterate & 37 & 69.8 & 13 & 24.5 & 3 & 5.7 & \\
\hline Read \& write & 75 & 72.8 & 17 & 16.5 & 11 & 10.7 & \\
\hline Basic education & 87 & 65.9 & 29 & 22.0 & 16 & 12.1 & \\
\hline Secondary & 232 & 67.2 & 71 & 20.6 & 42 & 12.2 & \\
\hline University & 149 & 60.6 & 51 & 20.7 & 46 & 18.7 & \\
\hline \multicolumn{7}{|l|}{ Mother education: } & \multirow{6}{*}{$0.000 *$} \\
\hline Illiterate & 107 & 74.8 & 16 & 11.2 & 20 & 14.0 & \\
\hline Read \& write & 72 & 74.2 & 20 & 20.6 & 5 & 5.2 & \\
\hline Basic education & 74 & 68.5 & 26 & 24.1 & 8 & 7.4 & \\
\hline Secondary & 219 & 63.7 & 81 & 23.5 & 44 & 12.8 & \\
\hline University & 108 & 57.8 & 38 & 20.3 & 41 & 21.9 & \\
\hline \multicolumn{7}{|l|}{ Father occupation: } & \multirow{7}{*}{0.366} \\
\hline Employee & 369 & 64.3 & 116 & 20.2 & 89 & 15.5 & \\
\hline Skilled worker & 25 & 67.6 & 8 & 21.6 & 4 & 10.8 & \\
\hline Free business & 132 & 68.0 & 44 & 22.7 & 18 & 9.3 & \\
\hline Farmer & 21 & 72.4 & 5 & 17.2 & 3 & 10.3 & \\
\hline Does not work & 18 & 85.7 & 1 & 4.8 & 2 & 9.5 & \\
\hline Unskilled worker & 13 & 61.9 & 6 & 28.6 & 2 & 9.5 & \\
\hline \multicolumn{7}{|l|}{ Mother occupation: } & \multirow{3}{*}{$0.024 *$} \\
\hline Housewife & 431 & 68.7 & 118 & 18.8 & 78 & 12.4 & \\
\hline Employee & 149 & 59.1 & 63 & 25.0 & 40 & 15.9 & \\
\hline
\end{tabular}

* Statistical significant difference $(P<0.05)$. 


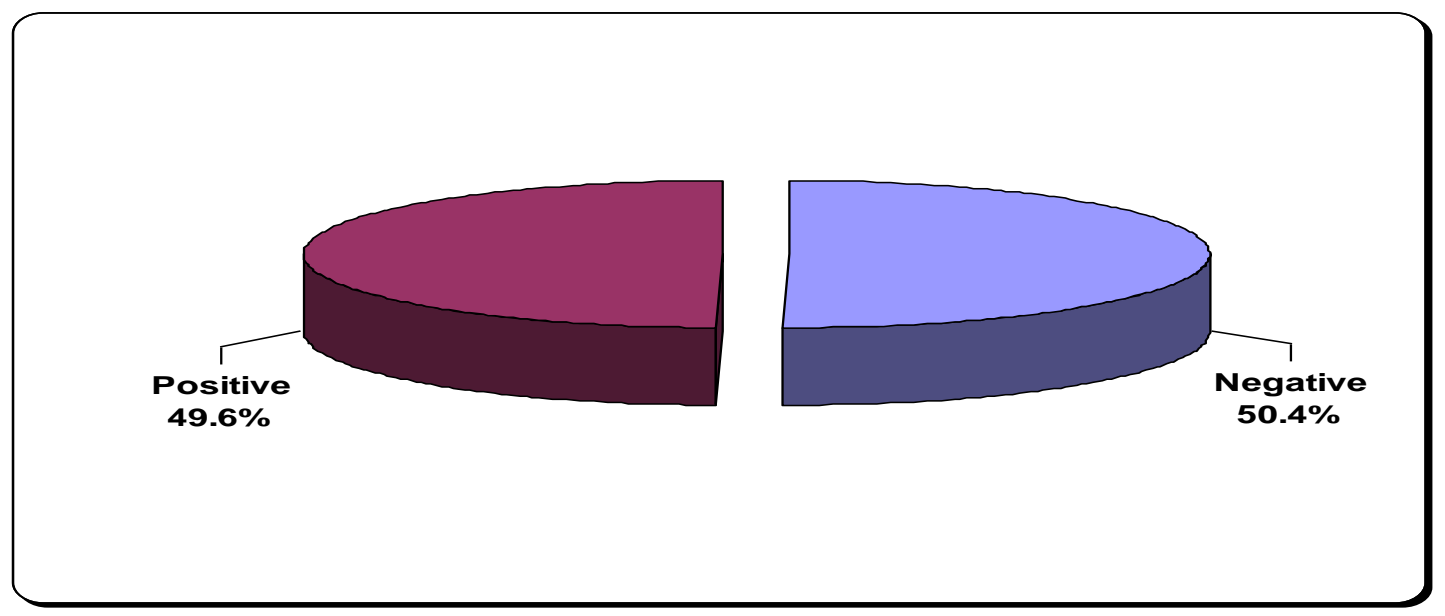

Figure(1): Total score of student's knowledge about premarital examination in secondary schools at Assiut city, 2017 $(n=879)$.

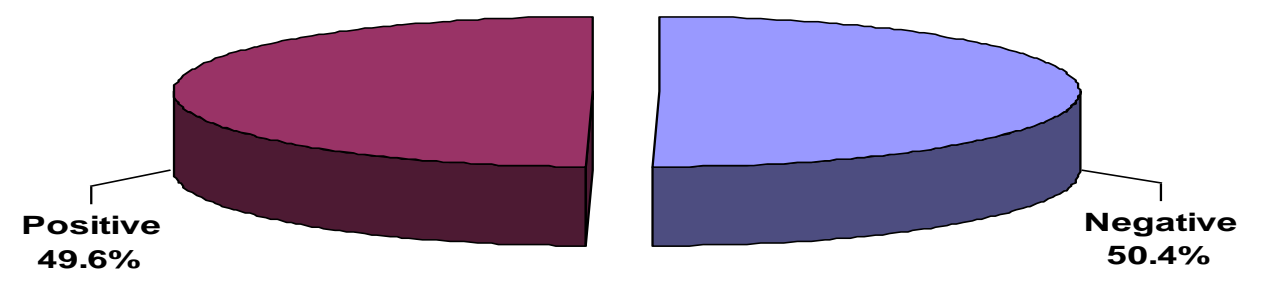

Figure (2): Total score of students attitude about premarital examination in secondary schools at Assiut city, 2017,(n=879).

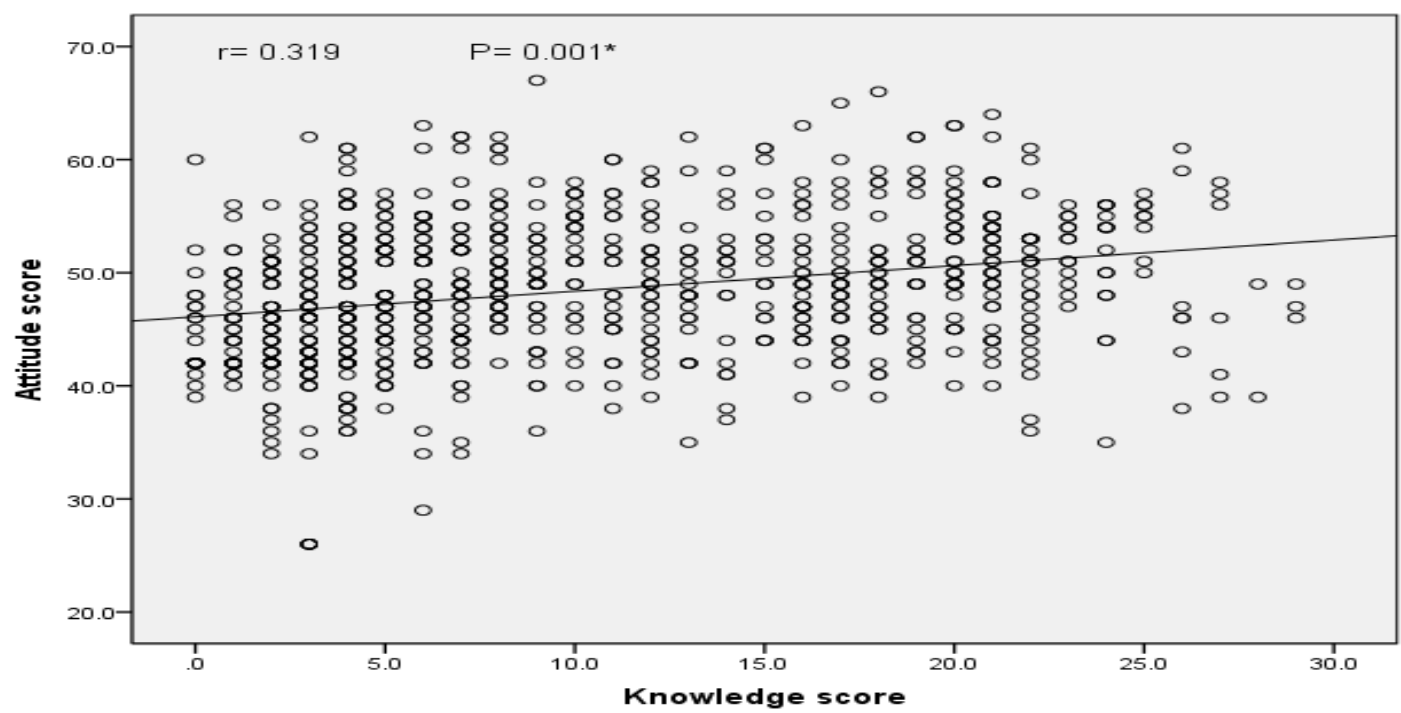

Figure (3): Correlation between knowledge and attitude of studied students about premarital examination. 
Table (1): Shows distribution of studied students regarding to their personal characteristics it was found that $53.1 \%$ of student's aged from $16-<18$ years and the mean age \pm SD was $16.26 \pm 1.14$. As regard to sex, $67.6 \%$ of students were females and $63.8 \%$ of them live in urban areas.According to parents education $(39.2 \% \& 39.1 \%)$ of student's fathers and mothers had secondary level of education respectively and only $(6.0 \% \& 16.3 \%)$ of students father and mother were illiterate respectively. Also the table estimated that $65.3 \%$ of students' father were employee, while $71.3 \%$ of students' mother were housewife.

Table (2): Distribution of studied students regarding to their knowledge about premarital examination in secondary school it was found that $50.9 \%$ of studied students mentioned that gain information about reproductive health is mainly importance of premarital examination, while $66.9 \%$ of them don't know disease can be detected by premarital examination,32.1\% knew Sexual transmitted diseases.

As regards premarital investigation; the table revealed that $35.7 \%$ of studied students said that examination of seminal fluid is consider from investigation of premarital examination followed by $(35.2 \% 34.8 \%, 33.8 \%, 33.7 \%)$ respectively stated that blood group analysis, rises factor analysis, complete blood count and diabetes analysis considered from premarital investigation.

Table (3): Cleared relation between student's knowledge about premarital examination and their parent's education \& occupation. It was observed that there were statistically differences between students knowledge and mother education; $\mathrm{p}$ - value = 0.000 .As well as between the mother occupation and their level of scoring knowledge $\mathrm{p}$ - value $=0.024$. On the other hand there weren't statistically differences between students knowledge \& father education ( pvalue $=0.151)$ As well as between the father occupation and their level of knowledge $(\mathrm{p}$ - value $=$ $0.366)$ respectively.

Figure(1): Cleared the total score of student's knowledge about premarital examination .It was illustrated that $66.0 \%$ of studied students had poor score of knowledge and $20.6 \%$ of them had satisfactory score of knowledge, while only( $13.4 \%$ )of them had good score of knowledge.

Figure(2): Presented the total score of students attitude about premarital examination indicated that $50.4 \%$ of studied students had negative and $49.6 \%$ of them had positive attitude toward premarital examination

Figure (3): Illustrated that a positive Correlation $\mathrm{r}=0.319$ between total score of students knowledge and their attitude about premarital examination with significant difference $\mathrm{p}=0.001$.

\section{Discussion}

Many young women and men come in into marriage with inadequate information on reproduction, family life, art of childhood, and family planning. Premarital examination is essential for prevention of genetic disorders, congenital anomalies, and common medical psychosocial marital problem. Moreover it gives the couples information about their tendency to certain diseases and the chances of passing on those diseases to their unborn children (Al-Farsi et al., 2014).

The results of the present study was found that more than half of student's age range from $16-<18$ years ,these results disagree with (Al-Nood et al., 2016 ) who found that three fifth of student's age $>20$ years old, moreover these results incompatible with (Al-Enezi \& Mitra ,2017) who presented that $66.6 \%$ of studied student's age 20-24 years old.

According to the student sex, the result of the present study revealed that slightly more than two thirds of students were females, This may be attribute to female students more committed to attend the schools than male .these results agree with (Al-Nood et al., 2016) who reported that three fifth of the studied students were female. Moreover these results disagree with (Ibrahim et al., 2013) who indicated that more than three quarter of the studied students were males.

As regards residence the present study cleared that more than three fifth of students live in urban area which disagree with (Abd Elfattah et al., 2015) who reported that $78 \%$ of studied students live in urban area ,Also these result inconsistent with ( Hassanain et al., 2011) who said that half of studied students live in urban area as well as the current results disagree with (Mohamdy et al., 2017) who cleared that $40.5 \%$ of studied students live in urban area and the existing results inconsistent with (Hejri et al., 2015) who indicated that $45.7 \%$ of studied students live in urban area.

According to parent's education the present study revealed that more than one third of student's fathers and mothers had secondary level of education which incompatible with (Mohamed et al., 2015) who cleared that more than two fifth of student's fathers and mothers had secondary level of education. This finding disagree with (Hassanain et al., 2011) who presented that $36.2 \%$ of studied students had secondary level and the current results inconsistent with (Hejri et al., 2015) who found that only $16.3 \%$ of studied students had secondary level of education. Concerning student's knowledge about importance of premarital examination the current study indicated 
that half of studied students mentioned that gain information about reproductive health as a main importance of premarital examination ;this might be attributed to studied students heard this information from their friends. Also the results of the present study was found that around one third of studied students mentioned Sexual transmitted diseases as main diseases can be detected by premarital examination and $37.4 \%$ of them didn't know; the current study agree with (Mohamed et al., 2015) who indicated that $41.0 \%$ of studied students didn't know, as well this finding disagree with (Al-Nood et al., 2016) who presented that the majority of studied students mentioned Sexual transmitted diseases as main Diseases can be detected by premarital examination and the present finding indicated that $35.7 \%$ of them mentioned that examination of seminal fluid as a main of premarital investigation, this might be due to student's concept that sperms are the basis of pregnancy.

Concerning to the total score of knowledge for students about premarital examination, this study revealed that around two thirds of studied students had poor score of knowledge and (only 13.4\%) had good score of knowledge ,these finding incompatible with (farahat et al., 2015) who cleared that half of students had good knowledge ,also the present result disagree with (Abd Elfattah et al., 2015) who reported that the majority of studied students had poor knowledge about premarital examination.

As regards student's attitude about premarital examination, the present study revealed that half of studied students had negative attitude and $49.6 \%$ had positive attitude, this might be due to lack of awareness of studied students toward premarital examination, this result consistent with(Mohamed et al., 2015) who found that half of studied students had positive toward premarital examination, its importance and the current results disagree with (AlEnezi \& Mitra, 2017) who presented that the majority of studied students had positive toward premarital examination.

In addition to the result of present study observed that there were statistically differences between students knowledge and mother education; $(\mathrm{p}$ - value $=0.000)$ ,while weren't statistically differences between students knowledge \& father education ( p- value= 0.151 ) this might be attributed to mothers more relative to their sons than father's.

In referral to the result of present study cleared that there positive Correlation between student's knowledge and attitude about premarital examination as the same line with (Mohamady et al., 2017) who said that that there positive Correlation between student's knowledge and attitude about premarital examination .

\section{Conclusion}

The study concluded that

Two thirds of studied students had poor score of knowledge about premarital examination while only more than one tenth of them had good score of knowledge. About half of studied students had negative attitude. Also there was a positive correlation between knowledge and attitude of them toward premarital examination

\section{Recommendation}

The study recommended that

1- Conducting counseling sessions with social workers in schools to convey information to students about premarital examination

2- Future research to replicate this study in other schools with different students to increase the ability to generalize the findings.

\section{Reference}

1. Abd El Rhman M., (2014): Knowledge and Opinion of Assiut University Students toward organ donation and transplantation thesis submitted for partial fulfiiment of the master degree in community health nursing pp 60-61

2. Ahmed A., Abd Al Azeem T., \& El Sherbiny A., (2015): Promotion of knowledge and attitude towards premarital care: An interventional study among medical student in Fayoum UniversityJournal of Public Health and Epidemiology 3(3), pp. 121-128

3. Ahmed S., (2017): Consanguineous Marriage among Egyptian Youth: Secondary Analysis of Survey of Young People in Egypt, The Egyptian Journal of Community Medicine , 35( 2):85-94

4. Al-Enezi K., \& Mitra A., (2017): knowledge ,Attitude, and satisfaction of university students regarding premarital screening program European Journal of Environment and Public Health,2017, 1(2), 1-7

5. Al-Erynai F., Al-Akmar M., \& Al-Nood A., (2016): Knowledge and Attitudes of Sana'a University Medical Students towards Premarital Screening Yemeni J Med Sci 2016;10:40-47.

6. Al-Farsi, O., Al-Farsi, Y., Gupta, I., Ouhtit, A., Al-Farsi, K., \& Al-Adawi, S., (2014): A study on knowledge, attitude, and practice towards premarital carrier screening among adults attending primary healthcare centers in a region in Oman. BMC Public Health, 14(1), 380 .

7. Al-Harbi S., Al-Mutairi D., \& Bushran A., (2015): Evaluating premarital screening knowledge in Saudi students Int J Community Med Public Health. 2015 Nov;2(4):540-551. 
8. Al-Nood, Hafiz A., Mohammed M., AlAkmar, \& Ekram F., Al-Erynai, (2016): "Knowledge and Attitudes of Sana'a University Medical Students towards Premarital Screening." Yemeni Journal for Medical Sciences 10:39-46.

9. Abd Elfattah H., Soliman M., \& Amin F., (2015): Premarital Genetic Counselling among Female Adolescents Students . Journal of American Science 2015;11(6)218-224

10. Farahat, T., Shaheen, H., Mohamed, H., \& Mohaseb, M., (2014): Knowledge and attitude of students in Menoufia University, ShebinElkom city toward premarital care .Menoufia Medical Journal, 27(2), 347

11. Gabriel O., \& Matthew C., (2013): Knowledge, Attitude and Practice of Premarital Counseling for Sickle Cell Disease Among Youth in Yaba, Nigeria African, Journal of Reproductive Health December 2013;17(4):175

12. Gu, Y., Li, L., Zhou, C., Yang, T., \& Dong, H., (2014): Factors influencing voluntary premarital medical examination in Zhejiang province, China: a culturally-tailored health behavioral model analysis. BMC public health, 14(1), 659 .

13. Hemamalini, N., (2017): Family Health "Begin Before You Start" -Premarital screening" International journal of scientific research (2017),6(2)78-46

14. Howard, N., (2015): Exploring the Effectiveness of MondatoryPremaritl screening and genetic counseling progragramms for BThalassaemia Public Health Genomics 2015;18(4):193-203

15. Hassanain A., Mohamed N., Ahmed H., \& Abdel Rahim S., (2011): Assessment of female adolescent Reproductive health needs in Assiut city Journal of American Science, 2011;7(12) 114

16. Ibrahim H., Ahmed A., \& Gadallah M., (2009): Nutritional and exercise habits for prevention of osteoporosis among female adolescent in Assiut City secondary school ,the new Egyptian journal of medicine:41;( 4),pp 346-356

17. Ibrahim, N., Bashawri, J., Al Bar, H., Al Ahmadi, J., Al Bar, A., Qadi, M., \& Feda, H., (2013): Premarital Screening and Genetic Counseling program: knowledge, attitude, and satisfaction of attendees of governmental outpatient clinics in Jeddah. Journal of infection and public health, 6(1), 41-54.

18. Jamiu, Q., (2016): Awareness and Attitude towards Premarital Health Screening for
Choice of Marriage International Journal of educational Benchmark; 4(1) 2016 109-115

19. Ministry of health portal-United Saudi Kingdom,(2017): Available at :https://www.moh.gov.sa.

20. Mohamed A., Lamadah S., \& Hafez S., (2015): Improving Knowledge and Attitude of Medical and Non-Medical Students at El Minia University Regarding Premarital Screening and Counseling American Journal of Nursing Science 2015; 4(5): 270-279

21. Mohamady S., Said S., Elsayed H., (2017): Effect of Application of Health Belief Model on females' Knowledge and Practice regarding the premarital counseling Journal of Nursing and Health Science 2017; 6 (1) 05-15

22. Rahman M., Naznin L., Giti S., Islam M., \& Khatun N., (2014): Premarital Health Screening JAFMC Bangladesh. V 10, (1) 2014

23. Alsaeed E., Farhat G., Assiri A., Memish Z., Ahmed E., Saeedi M., Al-Dossary M., \& Bashawri H., (2018): Distribution of hemoglobinopathy disorders in Saudi Arabia based on data from the premarital screening and genetic counseling program Journal of Epidemiology and Global Health 7 41-47

24. 24. The national counsil for childhood and motherhood, (2008): Available at :http://www.nccm-egypt.org. 